\title{
ANALYSIS OF POWER LOSSES IN 33/11 KV DISTRIBUTION FEEDER CIRCUITS VIA LOSS FACTOR TECHNIQUE
}

\author{
Hachimenum Nyebuchi Amadi, Senior Member IEEE \\ Department of Electrical and Electronics Engineering \\ Rivers State University, Port Harcourt, Nigeria \\ Email: \{hachimenum.amadi@ust.edu.ng\}
}

\begin{abstract}
Losses are among the major reasons for energy shortages and the inefficient operation of most power systems This study presents the analysis of power losses in five select 33/11KV distribution feeders (Etinan, Obot-Akara, Onna, Eket and Ibesikpo) in the Port Harcourt Electricity Distribution (PHED) network in Nigeria. Data comprising monthly loadings (MW) on the feeders, the cable type and route lengths including the sizes of distribution lines and feeder cables were obtained from the Utility. From these data, the annual power (technical) losses associated with the power transformers, the distribution lines and feeder circuits in the listed feeders were determined for the period January 2012 to December 2015. The study outcome revealed that the power losses incremented slightly yearly. These losses were found to be due to lack of maintenance of the power system components, transformer overloading, copper losses, core losses, lengthy feeder routes and deterioration/ageing of the transformers and other distribution components. A recommendation was made to reduce the level of the losses by fixing the afore-stated anomalies to achieve an improved performance of the electricity distribution network.
\end{abstract}

Key Words - Distribution Line Losses, Feeders, Technical Losses, Transmission Losses, Transformers

\section{Introduction}

The electrical system is divided into the generation, the transmission and the distribution subsystems. The primary purpose of the transmission and the distribution subsystems is to transfer economically and reliably the electrical energy produced by the generation subsystem over long distances to a point where the energy is available to the end-users.

About $40 \%$ of total investments in the electricity sector goes to the distribution subsector [1], still, the distribution subsystem is more troublesome than either the generation subsystem or the transmission subsystem because a significant part of the energy produced is often lost in the distribution subsystem.Electrical energy losses are among the major factors responsible for power distribution systems inefficiency and therefore unreliability. The higher the losses in the system, the more the outages signifying the inefficiency and unreliability of the power system [2].

As represented in Fig. 1, losses that occur in power system networks are classifiable into technical and nontechnical losses. Technical losses are natural being due to the material properties of the components that make up the system. These losses are due to the heat generated in transformers windings and iron cores, overhead lines and distribution lines.

The non-technical losses, on the other hand, are a result of factors external to the power system, for example, electricity theft arising from non-payment of electricity bills, billing errors, improper reading of meters, poor record-keeping, transformer overloading and defective meters, etc. [2].

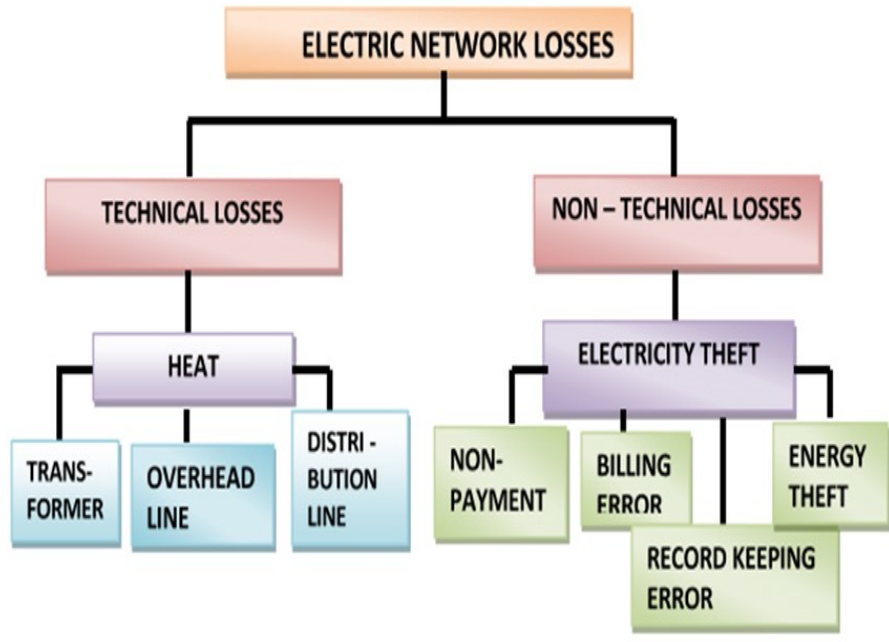

Fig. 1 Classification of losses [3]

Analysis of losses in power systems helps to ascertain and reduce the losses. Determining the loss level in a power transmission or distribution network facilitates its reduction and therefore enhances the system efficient and economic operation.

Different researchers in the area of power system studies have devised and applied different techniques all aimed at the accurate determination of the level of losses inherent in the system. 
Ref [4] studied the technical power losses in the University of Benin Teaching Hospital electrical distribution network using data accessed from the existing network in modelling the network in ETAP Software environment and analysing the developed power flow algorithm via the NewtonRaphson method. The findings showed that replacing the existing network feeders with larger-size conductors and compensator can help reduce the level of losses in the network.

During the same period, Ref [5] investigated the technical losses in select primary distribution feeders (Sango 33kv, Idiroko 33KV, Odigbo 33KV, Ilaro 33KV and Ota industrial $33 \mathrm{KV}$ feeders) in the Sango-Ota Distribution Company in Ogun State of Nigeria based on the monthly return loading, the feeder route lengths and cable type and found that losses in the feeders increased annually.

Ref [6] calculated the distribution power losses in the Baga Road Substation in Maiduguri, Bornu State, Nigeria by considering the daily loadings on some of the $11 \mathrm{KV}$ and $33 \mathrm{KV}$ distribution feeders for one month. The study outcome showed that more than $40 \%$ of the power loss was attributable to technical, non-technical and administrative losses in the distribution system.

Ref [7] investigated technical power losses in the Abeokuta distribution network based on data accessed from the Ibadan Electricity Distribution Company (IBEDC), Ijeun District, Abeokuta Ogun State of Nigeria in respect of select feeders domiciled in the Totoro, Kolobo, Abiola-Way, Ijeun-Titun, Ake-Road, GRA, Obantoko and Odeda areas of Ibadan for the period 2012 to 2014 using the loss factor approach. The outcome of the study revealed that high technical losses are attributable to lengthy feeder spans and illegal connections which result in feeder overloading.

Ref [8] computed the power losses in the Ekpoma distribution network using data from the Power Holding Company of Nigeria, Ekpoma covering January 2008 to December 2012. The study found that besides factors such as unbalanced loading of transformers, aged transformer, inadequate size of conductors etc., technical losses arising mainly from faults, conductor resistance and reactance contributed also to the power losses in the network.

Ref [9] while estimating the technical loss in a distribution system, applied the load factor and loss factor methodology and concluded that the technique is useful in loss estimation in power distribution systems.

Ref [10] calculated the power losses in a network by deploying the load factor and load loss factor using available data accessed from the electricity distribution company.

The study arrived at findings that could be deployed in the computation of financial losses by Regulators when determining electricity tariffs.

Ref [11] developed an approach which estimated distribution transformer (D.T.) losses in a feeder circuit whereby losses in each DT was computed and the total losses in the feeder circuit derived by summation of the losses due to each DT.

The present paper deploys the loss factor approach to compute the power losses on select feeders in the $33 / 11 \mathrm{KV}$ feeder circuits in the Port Harcourt electricity distribution network using data accessed from the substation. The feeders studied are the Etinan, Obot-Akara, Onna, Eket and Ibesikpo 33/11KV feeders. The Port Harcourt electricity distribution network provides power for more than 14 million people domiciled in 4 states of Nigeria namely Rivers, Akwa Ibom, Bayelsa and Cross River States [12]. All the $33 / 11 \mathrm{KV}$ feeders under study are serving the Akwa Ibom State.

\section{Materials and Method}

Data on monthly maximum loading, feeder route length and cable type (Aluminium conductor of size $150 \mathrm{~mm}^{2}$ having a resistivity of $2.82 \times 10-8 \Omega \mathrm{m}$ ) was used for both feeder and distribution lines) covering January 2012 to December 2015 was collected on each of the feeders under study. The feeders studied are the Etinan, Obot-Akara, Onna, Eket and Ibesikpo 33/11KV feeders feeding the Akwa Ibom. The monthly maximum loading (MW) on each of the feeders being investigated as accessed from the Utility for January 2012 to December 2015 is as shown in the Appendices section of this paper. This study deployed the loss factor approach in computing the technical power losses in these feeders.

Mathematically, loss factor is expressed as,

$$
L_{f}=\frac{\text { KVA average }}{\text { KVAMaxDemand }}
$$

The average energy losses or load loss factor during a designated period is given by the expression,

$$
L_{1 f}=\frac{\text { Actual Loss during a Period }(K W h)}{\text { Loss at Maximum Current }(K W h)}
$$

Loss factor and load loss factor are related to each other by the expression,

$$
L_{1 f}=K * L_{f}+(1-K) *\left(L_{f}\right)^{2}
$$

Where $\mathrm{K}$ is the co-efficient of loading,

$$
K=\frac{\operatorname{Minimum}(K V A)}{\operatorname{Maximum}(K V A)}
$$

The total power loss $\mathrm{W}_{\text {TLoss }}$ in $\mathrm{KW}$, in the power transformer is expressed as,

$$
W_{\text {TLoss }}=\left\{\operatorname{Loadloss}\left(W_{L}\right)+\text { NoloadLoss }\left(W_{N L}\right)\right\}^{*} 10^{-3}
$$


Where,

$$
W_{L}=W_{C}\left(\frac{K V A_{M D}}{K V A_{\text {Rating }}}\right) * L_{1 f}
$$

Where,

$W_{C}=$ Full load copper loss

$K V A_{M D}=$ Maximum KVA demand in a period

$K V A_{\text {Rating }}=\mathrm{KVA}$ rating of the transformer

The full load copper losses $\left(\mathrm{W}_{\mathrm{c}}\right)$ and the no-load losses $\left(\mathrm{W}_{\mathrm{NL})}\right.$ are often specified in the transformer standard losses Table.

Equations (5) and (6) combines yields,

$$
W_{T L o s s}=W_{C}\left(\frac{K V A_{M D}}{K V A_{\text {Rating }}}\right)^{2} * L_{1 f}+W_{N L}
$$

Expressed mathematically, power loss on the feeder,

$$
P_{\text {Loss }}=I_{L}^{2} R
$$

Putting the loss factor into consideration, equation (8) becomes,

$$
P_{\text {Loss }}=I_{L}^{2} R *(\text { LossFactor })
$$

Hence, we get,

$$
\begin{aligned}
\text { LossFactor }= & (0.3 * \text { LoadFactor })+0.7 \\
& *(\text { LoadFactor })^{2}
\end{aligned}
$$

and,

$$
\text { Load Factor }=\frac{\text { Average Load }}{\text { Peak Load }}
$$

The maximum current $\left(I_{L}\right)$ in Amperes (A) drawn from the feeder is given as,

$$
I_{L}=\frac{P}{\sqrt{3} V * p f}
$$

Given that the resistance, $\mathrm{R}$ in $\mathrm{Ohms}(\Omega)$ of the distribution line,

$$
R=\frac{\rho l}{A}
$$

Substituting equations (10), (12) and (13) into (9) yields,

$$
\begin{gathered}
P_{\text {Loss }}=\frac{P^{2} \rho l}{3 A(V * p f)^{2}}\{0.3 * \text { LoadFactor }+0.7 \\
\left.*(\text { LoadFactor })^{2}\right\}
\end{gathered}
$$

Where,

$P=$ Maximum monthly loading (MW) on the feeder

$\rho=$ Resistivity of the conductor $(\Omega \mathrm{m})$

$l=$ Route length of the feeder $(\mathrm{Km})$

$A=$ Cross-sectional area of the conductor $\left(\mathrm{mm}^{2}\right)$

$V=$ Voltage $(\mathrm{V})$

$P f=$ Power factor

$P_{\text {Loss }}=$ Power loss (MW) in the feeder

The total power loss in the system,

$$
\text { TotalLoss }=W_{\text {TLoss }}+P_{\text {Loss }}
$$

The flow chart for the computation of the power losses is shown in Figure 2.

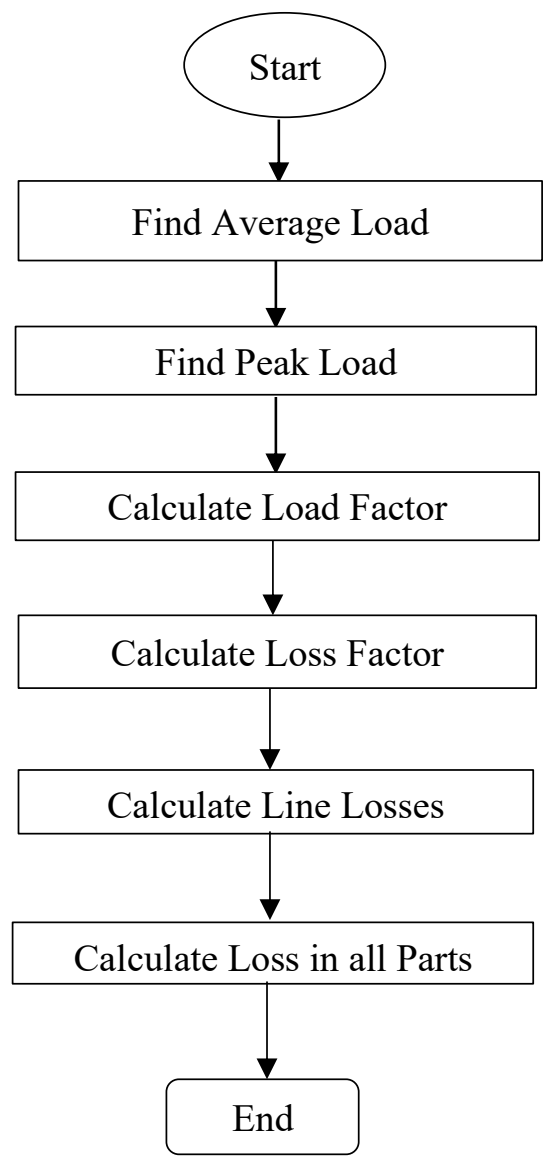

Fig. 2 Flow chart of the loss analysis process 


\section{Results and Description}

The power losses in five select feeders in the Port Harcourt electricity distribution network was determined using the loss factor approach. Tables 1 to 5 show the computed power losses (MW) on the feeders while Tables 6, 7 and 8 represent the Annual Average Maximum Loading (MW) on the Feeders, the Annual Average Power Losses (MW) on the Feeders and the Total Average Power Losses (MW) on the Feeders respectively from January 2012 to December 2015. Figures 3 and 4, on the other hand, show the Annual Average Maximum Loading on the Feeders and the Annual Average Power Losses on the Feeders respectively.
The losses were found to be highest in the Ibesikpo feeder (0.3610 MW), followed by the Etinan feeder (0.2066 MW), then the Eket feeder (0.1605 MW), the Obot-Akara feeder and least in the Onna feeder (0.0290 MW). These losses are attributable to poor maintenance of the power system components, transformer overloading, excessive feeder route length, etc. As shown in Table 8, during the period (January 2012 - December 2015) under study, the five feeders respectively recorded total average power loss of $0.872 \mathrm{MW}$ as follows: Obot-Akara (0.1149MW), Onna (0.029MW), Eket (0.1605MW), Etinan (0.2066MW) and Ibesikpo $(0.361 \mathrm{MW})$. The study outcome shows that there were slight increases in the losses on each feeder yearly.

Table 1. Computed Power Losses (MW) on Obot-Akara

$11 \mathrm{KV}$ Feeder from January 2012 to December 2015

\begin{tabular}{|l|l|l|l|l|}
\hline Month & $\mathbf{2 0 1 2}$ & $\mathbf{2 0 1 3}$ & $\mathbf{2 0 1 4}$ & $\mathbf{2 0 1 5}$ \\
\hline January & 0.0193 & 0.1384 & 0.1596 & 0.1285 \\
\hline February & 0.0158 & 0.1351 & 0.1592 & 0.1588 \\
\hline March & 0.0254 & 0.1416 & 0.1420 & 0.1800 \\
\hline April & 0.0197 & 0.1378 & 0.1586 & 0.1285 \\
\hline May & 0.0194 & 0.1362 & 0.1577 & 0.1590 \\
\hline June & 0.0166 & 0.1342 & 0.1596 & 0.1339 \\
\hline July & 0.0194 & 0.1460 & 0.1397 & 0.1718 \\
\hline August & 0.0211 & 0.1357 & 0.1546 & 0.1540 \\
\hline September & 0.0175 & 0.1501 & 0.1396 & 0.1448 \\
\hline October & 0.0185 & 0.1295 & 0.1616 & 0.1576 \\
\hline November & 0.0208 & 0.1306 & 0.1609 & 0.1427 \\
\hline December & 0.0194 & 0.1430 & 0.1481 & 0.1216 \\
\hline
\end{tabular}

Table 2. Computed Power Losses (MW) on Onna

$11 \mathrm{KV}$ Feeder from January 2012 to December 2015

\begin{tabular}{|l|l|l|l|l|}
\hline Month & $\mathbf{2 0 1 2}$ & $\mathbf{2 0 1 3}$ & $\mathbf{2 0 1 4}$ & $\mathbf{2 0 1 5}$ \\
\hline January & 0.0191 & 0.0264 & 0.0215 & 0.0318 \\
\hline February & 0.0264 & 0.0283 & 0.0277 & 0.0324 \\
\hline March & 0.0191 & 0.0376 & 0.0412 & 0.0307 \\
\hline April & 0.0175 & 0.0252 & 0.0253 & 0.0353 \\
\hline May & 0.0194 & 0.0251 & 0.0360 & 0.0330 \\
\hline June & 0.0186 & 0.0299 & 0.0241 & 0.0464 \\
\hline July & 0.0208 & 0.0342 & 0.0364 & 0.0370 \\
\hline August & 0.0206 & 0.0290 & 0.0246 & 0.0354 \\
\hline September & 0.0206 & 0.0296 & 0.0436 & 0.0412 \\
\hline October & 0.0179 & 0.0302 & 0.0288 & 0.0330 \\
\hline November & 0.0197 & 0.0288 & 0.0334 & 0.0420 \\
\hline December & 0.0187 & 0.0283 & 0.0256 & 0.0318 \\
\hline
\end{tabular}


Table 3. Computed Power Losses (MW) on

Eket $11 \mathrm{KV}$ Feeder from January 2012 to December 2015

\begin{tabular}{|l|l|l|l|l|}
\hline Month & $\mathbf{2 0 1 2}$ & $\mathbf{2 0 1 3}$ & $\mathbf{2 0 1 4}$ & $\mathbf{2 0 1 5}$ \\
\hline January & 0.0210 & 0.1675 & 0.1680 & 0.2243 \\
\hline February & 0.0224 & 0.1553 & 0.1619 & 0.2458 \\
\hline March & 0.0265 & 0.1513 & 0.1626 & 0.2250 \\
\hline April & 0.0270 & 0.1596 & 0.1567 & 0.2275 \\
\hline May & 0.0244 & 0.1273 & 0.1734 & 0.2250 \\
\hline June & 0.0226 & 0.1412 & 0.1714 & 0.2093 \\
\hline July & 0.6653 & 0.2632 & 0.1788 & 0.2285 \\
\hline August & 0.0221 & 0.1985 & 0.1716 & 0.1902 \\
\hline September & 0.0137 & 0.1556 & 0.1590 & 0.2850 \\
\hline October & 0.0248 & 0.1598 & 0.1650 & 0.2837 \\
\hline November & 0.0233 & 0.1777 & 0.1856 & 0.1658 \\
\hline December & 0.0265 & 0.1639 & 0.1787 & 0.2192 \\
\hline
\end{tabular}

Table 4. Computed Power Losses (MW) on Etinan 11KV Feeder from January 2012 to December 2015

\begin{tabular}{|l|l|l|l|l|}
\hline Month & $\mathbf{2 0 1 2}$ & $\mathbf{2 0 1 3}$ & $\mathbf{2 0 1 4}$ & $\mathbf{2 0 1 5}$ \\
\hline January & 0.1681 & 0.2160 & 0.2299 & 0.1660 \\
\hline February & 0.1742 & 0.2158 & 0.2672 & 0.2441 \\
\hline March & 0.1616 & 0.2014 & 0.2383 & 0.1637 \\
\hline April & 0.1534 & 0.2126 & 0.2551 & 0.1652 \\
\hline May & 0.1718 & 0.2100 & 0.2586 & 0.2327 \\
\hline June & 0.1716 & 0.2144 & 0.2447 & 0.1472 \\
\hline July & 0.1567 & 0.2324 & 0.2867 & 0.2354 \\
\hline August & 0.1650 & 0.2117 & 0.2396 & 0.2369 \\
\hline September & 0.1528 & 0.2189 & 0.2077 & 0.2441 \\
\hline October & 0.1829 & 0.2147 & 0.2171 & 0.1472 \\
\hline November & 0.1596 & 0.2014 & 0.2772 & 0.2188 \\
\hline December & 0.1398 & 0.2275 & 0.2734 & 0.1853 \\
\hline
\end{tabular}

Table 5. Computed Power Losses (MW) on Ibesikpo 11KV Feeder from January 2012 to December 2015

\begin{tabular}{|l|l|l|l|l|}
\hline Month & $\mathbf{2 0 1 2}$ & $\mathbf{2 0 1 3}$ & $\mathbf{2 0 1 4}$ & $\mathbf{2 0 1 5}$ \\
\hline January & 0.1577 & 0.3584 & 0.3881 & 0.4660 \\
\hline February & 0.1208 & 0.3767 & 0.4952 & 0.4465 \\
\hline March & 0.1080 & 0.3407 & 0.3800 & 0.4556 \\
\hline April & 0.1291 & 0.3666 & 0.4548 & 0.4500 \\
\hline May & 0.1674 & 0.3403 & 0.4424 & 0.4631 \\
\hline June & 0.1674 & 0.3634 & 0.3868 & 0.4571 \\
\hline July & 0.1454 & 0.3456 & 0.5016 & 0.6653 \\
\hline August & 0.1360 & 0.4384 & 0.4814 & 0.4543 \\
\hline September & 0.1265 & 0.3948 & 0.5176 & 0.4914 \\
\hline October & 0.1372 & 0.4268 & 0.4548 & 0.4738 \\
\hline November & 0.1729 & 0.3103 & 0.4438 & 0.4837 \\
\hline December & 0.1577 & 0.3638 & 0.4397 & 0.4814 \\
\hline
\end{tabular}




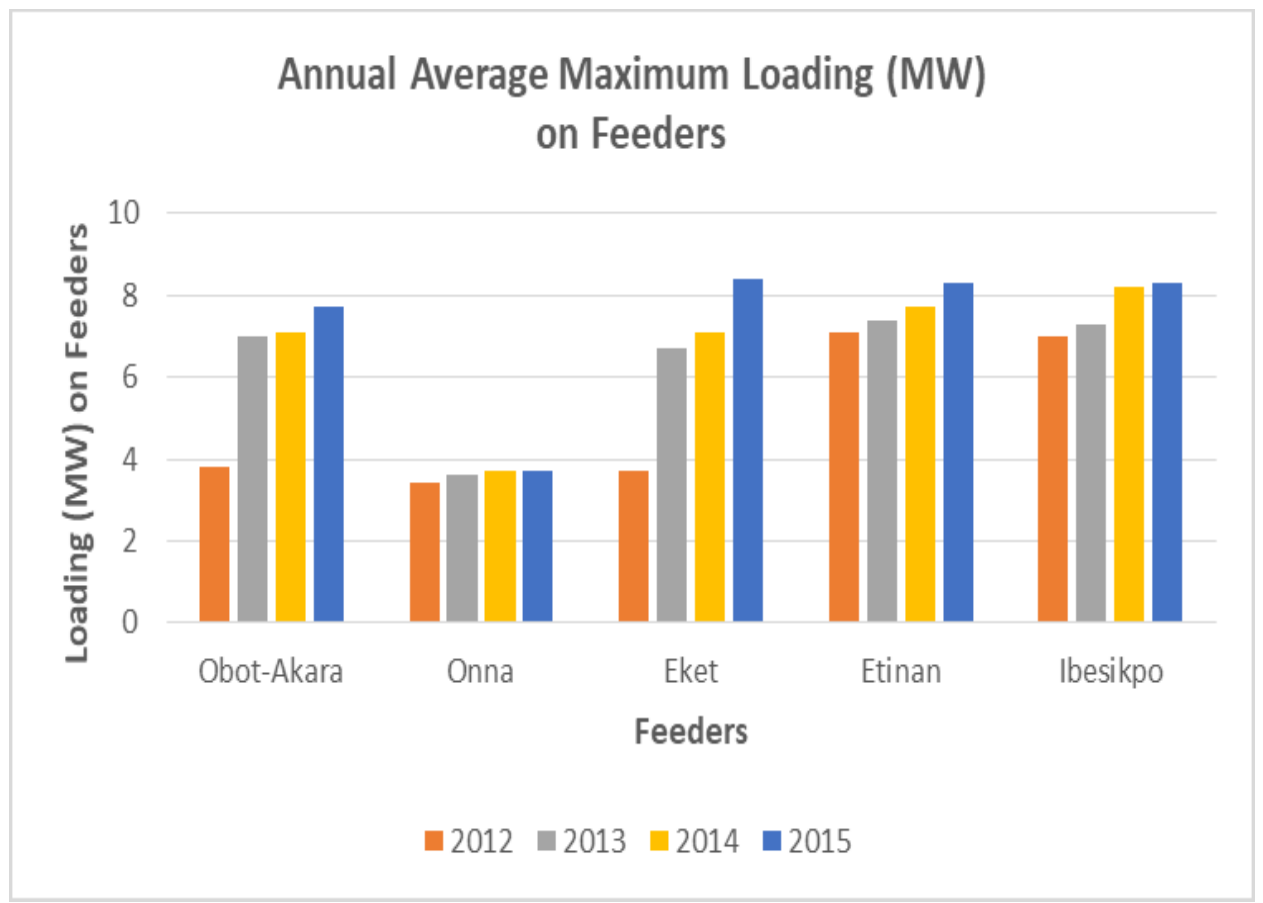

Fig. 3 Annual Average Maximum Loading on Feeders

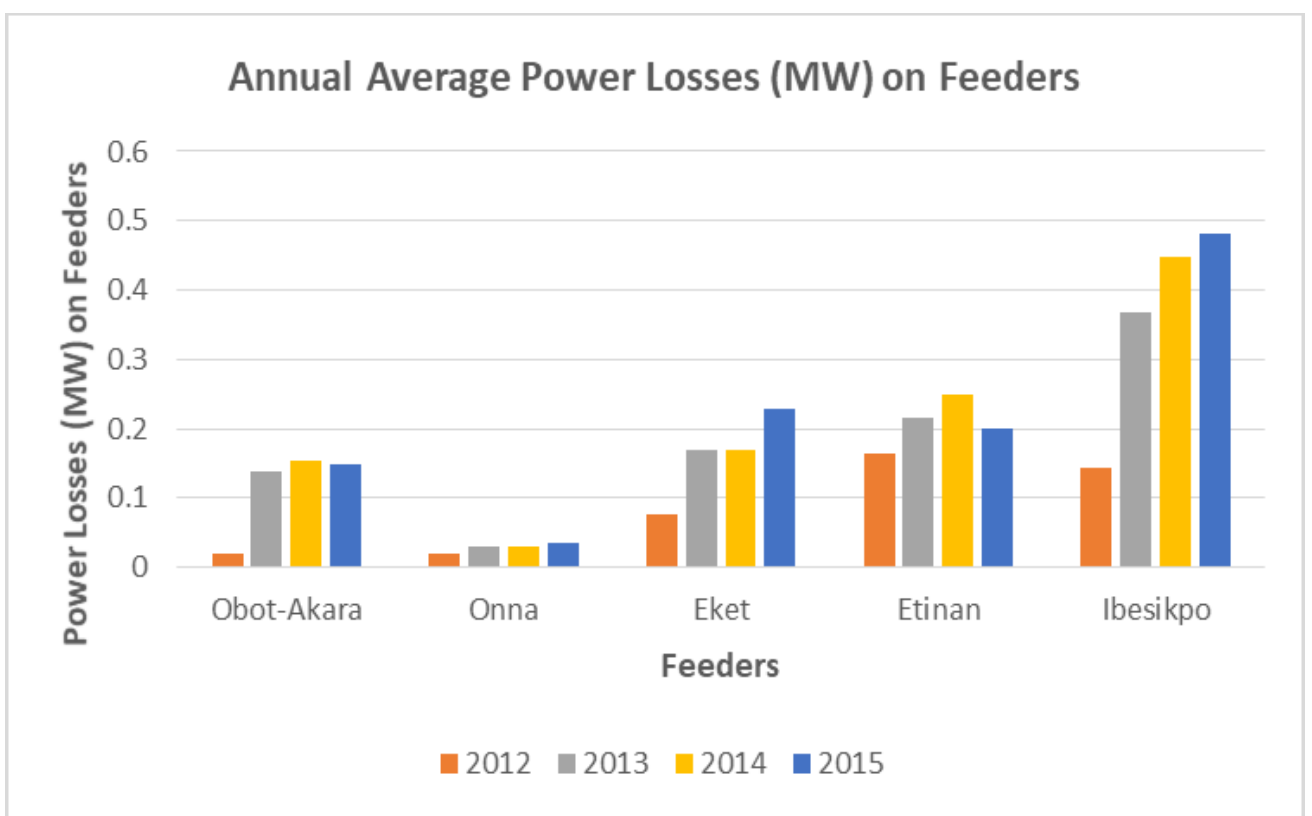

Fig. 4 Annual Average Power Losses on Feeders 
Table 6. Annual Average Maximum Loading (MW) on Feeders

\begin{tabular}{|l|l|l|l|l|}
\hline Feeder & Average Maximum Lading (MW) & $\mathbf{2 0 1 5}$ \\
\hline & $\mathbf{2 0 1 2}$ & $\mathbf{2 0 1 3}$ & $\mathbf{2 0 1 4}$ & 7.7 \\
\hline Obot-Akara & 3.8 & 7.0 & 7.1 & 3.7 \\
\hline Onna & 3.4 & 3.6 & 3.7 & 8.4 \\
\hline Eket & 3.7 & 6.7 & 7.1 & 8.3 \\
\hline Etinan & 7.1 & 7.4 & 7.7 & 8.3 \\
\hline Ibesikpo & 7.0 & 8.2 & \multicolumn{2}{l|}{} \\
\hline
\end{tabular}

Table 7. Annual Average Power Losses (MW) on Feeders

\begin{tabular}{|l|l|l|l|l|}
\hline Feeder & Average Power Losses (MW) & $\mathbf{2 0 1 5}$ \\
\hline & $\mathbf{2 0 1 2}$ & $\mathbf{2 0 1 3}$ & $\mathbf{2 0 1 4}$ & 0.1484 \\
\hline Obot-Akara & 0.0194 & 0.1382 & 0.1535 & 0.0359 \\
\hline Onna & 0.0199 & 0.0294 & 0.0307 & 0.2274 \\
\hline Eket & 0.0767 & 0.1685 & 0.1694 & 0.1988 \\
\hline Etinan & 0.1631 & 0.2147 & 0.2496 & 0.4824 \\
\hline Ibesikpo & 0.1439 & 0.3689 & 0.4489 & $\mathbf{1 . 0 9 2 9}$ \\
\hline Total & $\mathbf{0 . 4 2 3 0}$ & $\mathbf{0 . 9 1 9 7}$ & $\mathbf{1 . 0 5 2 1}$ & \\
\hline
\end{tabular}

Table 8. Total Average Power Losses (MW) on

Feeders from January 2012 to December 2015

\begin{tabular}{|l|c|}
\hline Feeders & $\begin{array}{l}\text { Total Average Power } \\
\text { Losses (MW) }\end{array}$ \\
\hline Obot-Akara & 0.1149 \\
\hline Onna & 0.0290 \\
\hline Eket & 0.1605 \\
\hline Etinan & 0.2066 \\
\hline Ibesikpo & 0.3610 \\
\hline Total & $\mathbf{0 . 8 7 2}$ \\
\hline
\end{tabular}

\section{Conclusion}

This study applied the loss factor approach and analysed the level of losses in five select $33 / 11 \mathrm{KV}$ feeders (Etinan, Obot-Akara, Onna, Eket and Ibesikpo) in the Port Harcourt electricity distribution (PHED) network using monthly loading (MW) on the respective feeders, the cable type and route lengths including the types and sizes of distribution lines and feeder cables obtained from the distribution substation office. The losses were found to be highest in the Ibesikpo feeder $(0.3610 \mathrm{MW})$, followed by the Etinan feeder (0.2066 MW), then the Eket feeder $(0.1605 \mathrm{MW})$, the Obot-Akara feeder and least in the Onna feeder (0.0290 MW).

The losses in the feeders were traceable to poor maintenance of the power system components, transformer overloading, copper losses, core losses and deterioration/ageing of the components, incessant illegal connections resulting to overloading of the feeders, excessive feeder route length, use of undersized cables/conductors, aged transformers and distant location of transformers from the load centres. The study recommends regular inspection, preventive and corrective maintenance of the electrical components, use of proper sizes of cables/conductor and timely upgrade of the transformers to minimize the power losses in the

ISSN (Print): 2456-6411 | ISSN (Online): 2456-6403 distribution network.

\section{References}

[1] Mustafa, S.S., Yasen, M.H. and Abdullah, H.H. (2011). Evaluation of Electric Energy Losses in Kirkuk Distribution Electric System Area, Iraq J. Electrical and Electronic Engineering, 7(2).

[2] H.N. Amadi, F. I. Izuegbunam and E. N. C. Okafor (2016). Evaluation of Losses in Distribution Networks of Selected Industrial Cities in Nigeria Using ETAP. British Journal of Applied Science \& Technology. 17(6): 1-12.

[3] Ademola, A.G. (2016). Evaluation and Mitigation of Technical Losses on Power Lines: A case study of Nigeria 330-kv Network. A PhD Thesis in Electrical and Electronics Engineering. Covenant University, Nigeria.

[4] Odiasea, O.F and O. Agbonaye (2018). Technical Power Losses reduction on Distribution Network of University of Benin Teaching Hospital. Int. J. Renew. Energ. \& Envir. Environ., 3,12- 27.

[5] Ade-Ikuesan, O. O.; Okakwu, I. K; Osifeko, M. O. and O.E. Olabode (2018). Investigation of Electric Power Losses on Primary Distribution Feeder: A Case Study of Sango - Ota Distribution Company, Ogun State, Nigeria. International Journal of Applied Engineering Research, 13(7), 50005003.

[6] Muhammad, A. A., Bukar, M.U. and A.M. Kura (2017). 
Evaluation and Effects of a Technical and Non-Technical Losseson $11 \mathrm{kv}$ and $33 \mathrm{kv}$ Feeders, a Case Study of Baga Road Substation, Maiduguri. International Journal of Engineering Inventions, 6(10),77-86.

[7] Mufutau, W.O.; Jokojeje, R.A.; Idowu, O.A. and M.A. Sodunke (2015).Technical Power Losses Determination: Abeokuta, Ogun State, Nigeria Distribution Network as a Case Study. IOSR Journal of Electrical and Electronics Engineering (IOSR-JEEE), 10 (6),01-10.

[8] Adegboyega, G.A. and Onime, F. (2014). Determination of Electric Power Losses in Distribution Systems: Ekpoma, Edo State, Nigeria as a Case Study. The International Journal of Engineering and Science (IJES), 3(01), 66-72.

[9] Keoliya, J.A. and Vaidya, G.A. (2013). Estimation of Technical Losses in a Distribution System. International Journal of Engineering Research \& Technology (IJERT),
[10] Pande, S. and J.G. Ghodekar, Computation of Technical Power Loss of Feeders and Transformers in Distribution System using Load Factor and Load Loss Factor, International Journal of Multidisciplinary Science and Engineering, 3(6), 2012, 22-25.

[11] Kulkarni, V.A. and P.K. Katti, Estimation of Distribution Transformer Losses in Feeder Circuit, International Journal of Computer and Electrical Engineering, 3 (5), 2011, 659-662.

[12] Port Harcourt Electricity Distribution Company. Available at

https://en.wikipedia.org/wiki/Port Harcourt Electricity D istribution Company, July 2019.

\section{Appendices}

\section{Appendix 1}

Monthly maximum loading (MW) on Obot-Akara Feeder from January 2012 to December 2015

\begin{tabular}{|l|l|l|l|l|}
\hline Month & $\mathbf{2 0 1 2}$ & $\mathbf{2 0 1 3}$ & $\mathbf{2 0 1 4}$ & $\mathbf{2 0 1 5}$ \\
\hline January & 3.7 & 7.2 & 7.0 & 8.2 \\
\hline February & 2.8 & 7.0 & 7.2 & 7.8 \\
\hline March & 6.2 & 7.2 & 6.6 & 8.0 \\
\hline April & 3.6 & 6.6 & 7.2 & 7.6 \\
\hline May & 3.6 & 7.0 & 7.4 & 8.0 \\
\hline June & 3.0 & 6.6 & 7.0 & 7.4 \\
\hline July & 3.6 & 7.8 & 7.4 & 7.2 \\
\hline August & 4.2 & 7.0 & 7.0 & 7.7 \\
\hline September & 3.4 & 7.0 & 6.5 & 7.6 \\
\hline October & 3.6 & 6.6 & 7.8 & 7.2 \\
\hline November & 4.2 & 7.0 & 7.2 & 7.2 \\
\hline December & 3.6 & 6.6 & 7.2 & 7.8 \\
\hline
\end{tabular}

Appendices 2

Monthly maximum loading (MW) on Onna Feeder from January 2012 to December 2015

\begin{tabular}{|l|l|l|l|l|}
\hline Month & $\mathbf{2 0 1 2}$ & $\mathbf{2 0 1 3}$ & $\mathbf{2 0 1 4}$ & $\mathbf{2 0 1 5}$ \\
\hline January & 2.8 & 3.4 & 2.4 & 3.4 \\
\hline February & 3.0 & 5.4 & 3.6 & 3.6 \\
\hline March & 5.0 & 3.6 & 4.8 & 3.4 \\
\hline April & 3.0 & 3.4 & 3.4 & 3.4 \\
\hline May & 2.8 & 3.6 & 3.6 & 3.4 \\
\hline June & 3.4 & 3.4 & 3.6 & 5.8 \\
\hline July & 3.6 & 3.7 & 3.6 & 3.6 \\
\hline August & 3.4 & 3.6 & 3.4 & 3.6 \\
\hline September & 3.4 & 3.6 & 6.4 & 3.7 \\
\hline October & 3.6 & 3.0 & 3.4 & 3.4 \\
\hline November & 3.4 & 3.6 & 3.6 & 3.6 \\
\hline December & 3.0 & 3.4 & 3.4 & 3.4 \\
\hline
\end{tabular}

\section{Appendix 3}


Monthly maximum loading (MW) on Eket Feeder from January 2012 to December 2015

\begin{tabular}{|l|l|l|l|l|}
\hline Month & $\mathbf{2 0 1 2}$ & $\mathbf{2 0 1 3}$ & $\mathbf{2 0 1 4}$ & $\mathbf{2 0 1 5}$ \\
\hline January & 3.4 & 6.0 & 7.0 & 8.4 \\
\hline February & 3.6 & 7.2 & 6.2 & 9.4 \\
\hline March & 4.6 & 6.4 & 6.6 & 8.4 \\
\hline April & 4.2 & 6.2 & 6.6 & 8.2 \\
\hline May & 3.6 & 6.4 & 7.0 & 8.4 \\
\hline June & 3.6 & 6.0 & 7.8 & 8.4 \\
\hline July & 3.6 & 8.4 & 6.6 & 8.4 \\
\hline August & 3.6 & 7.4 & 7.0 & 8.4 \\
\hline September & 3.4 & 7.0 & 6.2 & 8.2 \\
\hline October & 3.6 & 6.0 & 7.0 & 9.6 \\
\hline November & 3.6 & 7.0 & 8.2 & 7.2 \\
\hline December & 3.6 & 6.0 & 8.2 & 8.2 \\
\hline
\end{tabular}

\section{Appendix 4}

Monthly maximum loading (MW) on Etinan Feeder from January 2012 to December 2015

\begin{tabular}{|l|l|l|l|l|}
\hline Month & $\mathbf{2 0 1 2}$ & $\mathbf{2 0 1 3}$ & $\mathbf{2 0 1 4}$ & $\mathbf{2 0 1 5}$ \\
\hline January & 6.8 & 7.2 & 8.4 & 8.4 \\
\hline February & 7.2 & 7.8 & 7.2 & 8.4 \\
\hline March & 7.2 & 7.2 & 7.2 & 8.0 \\
\hline April & 7.0 & 7.2 & 7.2 & 8.2 \\
\hline May & 7.2 & 7.2 & 8.2 & 8.4 \\
\hline June & 8.0 & 7.8 & 7.4 & 8.2 \\
\hline July & 7.0 & 7.4 & 7.4 & 8.0 \\
\hline August & 7.0 & 7.4 & 8.4 & 8.0 \\
\hline September & 7.0 & 7.6 & 7.4 & 8.4 \\
\hline October & 7.2 & 7.2 & 8.2 & 8.4 \\
\hline November & 6.6 & 7.2 & 8.2 & 8.4 \\
\hline December & 7.0 & 7.3 & 7.2 & 8.6 \\
\hline
\end{tabular}

\section{Appendix 5}

Monthly maximum loading (MW) on Ibesikpo Feeder from January 2012 to December 2015

\begin{tabular}{|l|l|l|l|l|}
\hline Month & $\mathbf{2 0 1 2}$ & $\mathbf{2 0 1 3}$ & $\mathbf{2 0 1 4}$ & $\mathbf{2 0 1 5}$ \\
\hline January & 7.2 & 7.2 & 7.3 & 8.4 \\
\hline February & 6.7 & 7.3 & 8.2 & 8.4 \\
\hline March & 6.1 & 7.4 & 7.4 & 8.2 \\
\hline April & 6.2 & 7.0 & 8.4 & 7.8 \\
\hline May & 6.6 & 7.2 & 8.4 & 8.4 \\
\hline June & 7.2 & 7.2 & 7.3 & 8.2 \\
\hline July & 7.2 & 8.4 & 8.4 & 8.8 \\
\hline August & 7.0 & 8.4 & 8.4 & 8.2 \\
\hline September & 7.8 & 7.2 & 8.4 & 8.4 \\
\hline October & 7.4 & 7.4 & 8.4 & 8.2 \\
\hline November & 7.2 & 6.2 & 8.4 & 8.2 \\
\hline December & 6.6 & 7.4 & 8.4 & 8.4 \\
\hline
\end{tabular}

